"Relationship between environmental pressure and environmental disclosure in the sustainability reports of banks"

\begin{tabular}{|c|c|}
\hline AUTHORS & $\begin{array}{l}\text { Nyiko D. Mchavi } \\
\text { Collins C. Ngwakwe (D http://orcid.org/0000-0002-6954-8897 }\end{array}$ \\
\hline ARTICLE INFO & $\begin{array}{l}\text { Nyiko D. Mchavi and Collins C. Ngwakwe (2017). Relationship between } \\
\text { environmental pressure and environmental disclosure in the sustainability reports } \\
\text { of banks. Environmental Economics, 8(3), 111-118. doi:10.21511/ee.08(3- } \\
\text { 1).2017.03 }\end{array}$ \\
\hline DOI & http://dx.doi.org/10.21511/ee.08(3-1).2017.03 \\
\hline RELEASED ON & Wednesday, 11 October 2017 \\
\hline RECEIVED ON & Tuesday, 13 June 2017 \\
\hline ACCEPTED ON & Wednesday, 12 July 2017 \\
\hline LICENSE & $\begin{array}{l}(c) \text { EY } \\
\text { This work is licensed under a Creative Commons Attribution } 4.0 \text { International } \\
\text { License }\end{array}$ \\
\hline JOURNAL & "Environmental Economics" \\
\hline ISSN PRINT & $1998-6041$ \\
\hline ISSN ONLINE & $1998-605 X$ \\
\hline PUBLISHER & LLC "Consulting Publishing Company "Business Perspectives" \\
\hline FOUNDER & LLC "Consulting Publishing Company "Business Perspectives" \\
\hline
\end{tabular}

NUMBER OF REFERENCES

46

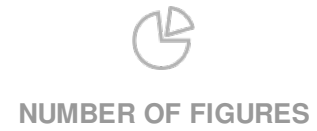

0
NUMBER OF TABLES

2

(C) The author(s) 2023. This publication is an open access article. 
Nyiko D. Mchavi (South Africa), Collins C. Ngwakwe (South Africa)

\title{
Relationship between environmental pressure and environmental disclosure in the sustainability reports of banks
}

\begin{abstract}
This research evaluates the role of environmental pressure on the extend of environmental disclosure of South African banks. Although much research on corporate sustainability disclosure exists, this research is unique since little of the previous research in South Africa has given a closer examination of environmental pressure implication on the banking sector environmental disclosure. Research data were collected from secondary source, which are available from the sustainability reports of the sample of banks. Data were arranged and analyzed by means of the panel data multiple regression. Findings from the analysis showed that none of the seven environmental pressure variables had a significant relationship with banks' environmental disclosure, which confirms assertion in the literature that banks are not much concerned with environmental issues. In conclusion, the research made some recommendations, which include that future researchers should expand the number of banks by including other financial institutions. Additionally, more research should be conducted to ascertain why external pressure is not very effective in motivating banks' environmental disclosure as found in this study. Hence, the suggested question for further research is "what motivates bank's environmental disclosure" and "do banks internalize or externalize their environmental costs".
\end{abstract}

Keywords: environmental disclosure, environmental pressure, sustainability disclosure, environmental accounting, environmental economics.

JEL Classification: Q01, Q5, Q50, Q56, Q57.

Received on: $13^{\text {th }}$ of June, 2017.

Accepted on: 12 $2^{\text {th }}$ of July, 2017.

\section{Introduction}

Corporate sustainability started gaining importance generally as a result of external pressures on big public firms (Wolf, 2014). Notable events leading to a widespread call for corporate sustainability obedience include "The proposed sinking of the Brent Spar oil platform" (Kolk \& Levy, 2001, p. 506; Naimi, 2011) in 1995, which resulted in societal concern for greater environmental accountability from companies. Another major external pressure came from the Brundtland Report in 1987 (WCED, 1987; Sen, 2013) and the Kyoto Protocol Climate Conference in 1997, which resulted in global awareness and call for sustainable development. Since then, research has identified several interested users of information contained in corporate environmental disclosure. According to Manetti and Toccafondi (2014), therefore, corporations are attempting to operate in a manner that can please these external interests. Accordingly, previous research on corporate sustainability reporting indicates that such reports improve corporate transparency and increase the

(C) Nyiko D. Mchavi, Collins C. Ngwakwe, 2017.

Nyiko D. Mchavi, MCom Candidate, School of Accountancy, Faculty of Management and Law, University of Limpopo, South Africa.

Collins C. Ngwakwe, Ph.D., Professor, Turfloop Graduate School of Leadership, Faculty of Management and Law, University of Limpopo, South Africa.

This is an Open Access article, distributed under the terms of the Creative Commons Attribution 4.0 International license, which permits unrestricted re-use, distribution, and reproduction in any medium, provided the original work is properly cited. reputation of corporations (Dingwerth \& Eichinger, 2014; Bertels \& Peloza, 2008). Given that South Africa is globally known for its involvements in sustainable development campaigns, this research intends to evaluate whether South African banks are influenced toward environmental responsibility disclosure by external pressure, especially given that environmental issues have progressed from standalone reports to be included in the sustainability reports of companies (Arnold et al., 2013). Although previously environmental disclosure has been voluntary in nature (Peters \& Romi, 2013), the recommendation for inclusion of environmental issues in the sustainability report by King III and the adoption by the JSE (De Villiers et al., 2014) indicate some form of pressure on companies to comply with environmental disclosure (Stubbs et al., 2013). The influence of such pressure on firms toward the preparation of integrated reports is therefore important as a subject of research to the benefit of academic and public awareness.

Consequently, the major objective for this research is to examine a possible relationship between external pressure and corporate environmental disclosure in the sustainability reports of South African banks. Therefore, the main research question for this paper is how environmental pressure relates with environmental disclosure in South African banks.

The succeeding sections of this article are organized in the following structure: after this introduction, the literature review is presented, which begins with linking the paper with legitimacy theory followed by a 
review of related empirical research. Following the literature review, the paper presents a detailed description of the method used in the research, including the analytical method. This is followed by the results and their discussion. The final section presents the recommendations and conclusion.

\section{Literature review}

1.1. Legitimacy theory. The main concern of the legitimacy theory is that organizations attempt to operate within the prescribed and required norms of their various societies (Hahn \& Kühnen, 2013) to remain legitimate in the eyes of society. Therefore, the legitimacy theory is described as "a generalized perception or assumption that the actions of an entity are desirable, proper, or appropriate within some socially constructed system of norms, values, beliefs and definitions" (Suchman, 1995, p. 574). Glozer et al. (2014) agree. Therefore, to ensure desirability of corporate activities, organizations try to ensure that environmental values are integrated within their operations to legitimize their existence (Dowling \& Pfeffer, 1975, p. 122; Cho et al., 2013).

Therefore, the legitimacy theory is relevant and related to the study, because corporate sustainability disclosure has remained mostly voluntary, but currently disclosure is shifting from a mere voluntary position to some form of compulsory demand through external pressures and this therefore means that firms are encouraged to disclose. This demanded aspect, which may be regarded as external pressure, is the concern of the legitimacy theory. Therefore, the legitimacy theory is also used to support this research, given that banks may likely be under pressure to comply with the environmental disclosure demand of external pressure to gain legitimacy. Disclosure of these environmental values, therefore, is a tool of legitimacy by organizations and this is relevant to South African banks in this research given the South African society's growing awareness and demand for corporate environmental responsibility.

\subsection{External pressure and corporate} environmental disclosure in integrated reports. Research indicates that there is a wide variety of external pressure that influences how companies respond to sustainability disclosure. These pressures include, among others, the government, political pressure, social pressure, regulatory pressure and customer pressure (Font, Guix, \& Bonilla-Priego, 2016; Dissanayake, Tilt, \& Xydias-Lobo, 2016).

Arguments in support of external pressure for corporate environmental disclosure have also been presented by different authors in different tones of argument. According to Meng et al. (2013), firms with poor environmental performance have been found to face more political and social pressure that weaken their legitimacy. Therefore, they could be relied upon to give more broad off-setting or positive environmental disclosures in their annual reports to external stakeholders (Meng et al., 2013). The research also found that reliance on external sources of finance, such as the stock exchange, plays a role in influencing firms to engage in environmental disclosure to attract capital support from the external stock suppliers. It is believed therefore, that firms within the stock exchange disclose more environmental reports to boost their ability to attract external capital to run their business (Ledoux et al., 2014). In their study on environmental performance and environmental reporting, Meng et al. (2014) posit that companies that are perceived by regulatory authorities as violating environmental standards are more likely to provide more environmental disclosure in their integrated reports. Others have argued that external pressure attracts environmental disclosure in firms that primarily use the disclosure to demonstrate environmental leadership and to divert public attention away from real problems of the firm (Peters \& Romi, 2013). However, Peters and Romi (2013) did not highlight the negative consequences of pretentious environmental disclosure to companies and to the society at large. Still, in support of external pressure, other research has also disclosed that an industry's environmental impact positively associates with its degree of environmental disclosure (Barbu et al., 2014) for compliance reasons. In their study, Hassan and Ibrahim (2012) found that industry membership may influence the level of environmental disclosure in a company's integrated report. In another similar study, Hahn and Kühnen (2013) found that listing on the stock exchange affects the level of company's environmental disclosure and that a country's culture might impact the extent of environmental and/or sustainability disclosure by companies (Legendre \& Coderre, 2013).

According to Brennan and Merkl-Davies (2014), external pressure tends to influence corporate environmental disclosure, because there is a range of external pressures that demand environmental accountability from corporations. These include environmental organizations, governments and the public. Hence, in his summary of research findings, Tan (2014) highlights that mandatory regulatory requirements have led to a positive shift in management environmental disclosure strategy. Furthermore, Llena et al. (2007) report in their 
empirical findings of the increase in environmental reporting by Spanish firms that resulted from the introduction of compulsory environmental accounting standards in Spain. Also in a crosscountry study of the influence of commercial and environmental laws, Jorgensen and Soderstrom (2006) and Mallin et al. (2013) found that existing country legal institutions, environmental regulations and disclosure regulations positively affect corporate environmental disclosure. In these studies, attention was not given to whether this external pressure leading to disclosures was reliable.

In the Republic of South Africa, the King III Code of Corporate Governance and the JSE are additional external pressures that encourage companies in SA to disclose environmental information in their annual integrated reports, especially considering the comply or explain clause (Soltani \& Maupetit, 2014; Singh \& Verma, 2014).

Similar to the arguments against external pressure and social disclosure are also the arguments against the popular literature view that corporate environmental disclosure is primarily initiated by external pressure. For instance, there are arguments that, rather than external pressure, corporate internal environmental ethical codes of conduct seem to be the determinant of the level of corporate environmental disclosure (Weaver et al., 1999; Epstein \& Buhovac, 2014). This argument is supported by research findings that external pressure that biases conduct, produces more artificial and not dependable reports than internally learned ethics (Talbot \& Boiral, 2014), and, therefore, that externally influenced environmental disclosure is often, in many cases, far from the truth and thus unreliable regarding the real corporate environmental commitment. The argument against the effectiveness of external pressure on environmental disclosure was demonstrated in Amran and Haniffa (2011) in which they found that despite strong environmental pressure in Malaysia, only government affiliated company showed improvement in environmental disclosure. This finding is supported by Stubbs and Higgins (2014) who argue that, rather than external pressure, it is corporate internal mechanisms of change that drive a trustworthy environmental disclosure by corporations. Tilt (2001) argues strongly that empirical evidence that pressure group influence corporate environmental reporting is very scanty. Tilt (2001) finds on the contrary that, rather than pressure groups influencing reporting, they prefer attempting or lobbying to influence corporate environmental activities, but not reporting (Tilt, 2001, pp. 7-8). Tilt (2001) further indicates that literature pointing to external pressure influence on environmental reporting is merely based on allusions. Thus, according to Tilt (2001, p. 8), "Few of these studies, however, cite any evidence and appear to rely on it being 'common knowledge' that such activities take place". This present study however, used evidence from the integrated reports of South African banks to demonstrate if there is any association between external pressure and environmental disclosure. Doing so adds a new dimension to existing literature by providing practical evidence to literature claims about external pressure and corporate environmental reporting. This is in compliance with Adams' (2004) suggestion that corporate environmental disclosure can be understood by studying information contained in the corporate sustainability reports.

\section{Method and analysis}

The target population for this study is the South African banking industry listed in the Johannesburg Stock Exchange Socially Responsible Index (SRI). The reason for this population choice is that previous studies on sustainability disclosure in South Africa have paid little attention to environmental disclosure in the banking industry, especially regarding the influence of environmental pressure. However, the purpose sampling approach was applied to further narrow the sample to three banks, because only about three banks contained consistent information on environmental disclosure in sustainability reports within the period of study (2010-2015); this is not to say that other banks did not, but consistency was the deciding factor behind the purposive sample selection.

The paper used a mixed method of quantitative and qualitative approaches. Creswell (2014) explains that a mixed method is applicable when the researcher combines quantitative data or analysis with qualitative information, stories or experience, which, according to Creswell (2014), provides a more reliable understanding of the research problem than when either of the methods are used individually. Accordingly, the method of collecting data in this research was through content analyses of the integrated reports of banks, which is a qualitative process. Content analysis has been used in former sustainability disclosure studies such as in Ihlen and Roper (2014) and Hahn and Lülfs (2014). However, this research used a quantitative approach to analyze the data after collecting the environmental and external pressure contents from the integrated reports of banks, and data analysis was conducted using the multiple regression statistics. 
The final number of banks used in this analysis was reduced to three, because only three banks contained the complete consistent data needed for the analysis over the six years period 2010 to 2015 . These years were chosen, because the integrated report of King III realized in 2009 came into operation in 2010. Hence, the research chose the data collection for the period 2010 to 2015 . Therefore, because the small number of banks was used due to data limitation, the paper applied the panel data analysis method, which enabled the overall data to constitute 18 observations ( 3 banks $\times 6$ time series $=$ eighteen observations). The eighteen observations were then used in the panel data multiple regression analysis in the following sections.

\section{Data analysis approach}

With the application of content analysis, external pressure variables picked from the integrated reports of banks. After this, a relationship between the external pressure variables and environmental disclosure was examined using the panel data multiple regression statistics. Previous researches on sustainability disclosure have applied the panel data and multiple regression analysis to study corporate environmental disclosure, these include studies on the determinants of sustainability statements (Kolk \& Perego, 2010), sustainability disclosure in UAE banks (Nobanee \& Ellili, 2016) and corporate social disclosure as an indication of social performance (Yilmaz, 2016).

From the review of empirical literature, sources of external pressure for corporate environmental disclosure can be summarized as regulatory, government, society, political and customers. Since there are internal management objectives for environmental disclosure, the researchers added internal objectives (to serve as control variables in this analysis). According to previous literature, the most cited internal objectives for environmental disclosure are profit objective and firm reputation (James, 2015; Hogarth, Hutchinson, \& Scaife, 2016). Therefore, five external independent variables plus two internal independent variables were used in the regression model.

According to Canham et al. (2003), the problem with relational research is that in the natural world, the independent variable is not always the sole influential factor on the dependent variable. This is because the natural system is not always closed, hence, Canham et al. (2003) suggest that "when we test a theory by its consequences, other potentially influential factors have to be held constant" (Canham et al., 2003, p. 16) to enable a preliminary and non-general conclusion about the relationship being examined. In this research, therefore, apart from external environmental pressure, the researchers tried to include control variables, which are profit objectives and firm reputation (not very exhaustively though). Apart from these control variables, other factors that influence environmental disclosure are temporarily held constant to enable the researchers to make a tentative conclusion, which is limited to this research. This limited assumption therefore offers a research opening for other researchers to examine this topic in future by inclusion of as many independent variables as possible.

3.1. The regression model. The review of literature indicates that sources of external pressure for corporate sustainability disclosure include regulation, government, society, political and customers. The researchers added internal objectives (control variable) for sustainability disclosure, which, according to the literature, are profit objectives and firm reputation. Therefore, five external independent variables plus two internal independent variables were used in the regression model as follows:

$$
\begin{aligned}
& Y=\beta o+\beta_{1} \chi_{1}+\beta_{2} \chi_{2}+\quad \beta_{3} \chi_{3}+\beta_{4} \chi_{4}+\beta_{5} \chi_{5}+\beta_{6} \chi_{6}+ \\
& +\beta_{7} \chi_{7}+\varepsilon
\end{aligned}
$$

where:

$Y=$ dependent variable ( environmental disclosure);

$\beta 0=$ the intercept;

$\beta_{1-7}=$ the regression coefficient;

$\chi_{1-5}=$ main independent variables (external pressure variables, which are: Regulatory pressure, government pressure, social pressure, customer pressure, political pressure;

$\chi_{6-7}=$ control variables (profit objective, reputational objective);

$\varepsilon=$ represents the error.

Research question: What relationship exists between external pressure and corporate environmental disclosure in the integrated reports of South African banks?

Research hypothesis: H0: there is no relationship between external environmental pressure and environmental disclosure

Decision criterion: the relationship was tested at an alpha of 0.05 significance level. Therefore, a significant relationship was assumed to exist if the regression p-value for any of the independent variables (environmental pressure variables) is $\mathrm{P} \leq 0.05$. 
Table 1. Regression output on the test of hypothesis model 2: fixed-effects, using 18 observations included 3 cross-sectional units time-series length $=6$ dependent variable: EnvirDiscl

\begin{tabular}{|l|c|c|c|c|}
\hline & Coefficient & Std. Error & t-ratio & $p$-value \\
\hline const & 3276.15 & 2525.63 & 1.2972 & 0.23073 \\
\hline RegPress & -48.3381 & 41.946 & -1.1524 & 0.28243 \\
\hline GovPress & -77.2031 & 41.9042 & -1.8424 & 0.10267 \\
\hline SocPress & 7.82218 & 41.5185 & 0.1884 & 0.85525 \\
\hline PolitPress & -101.517 & 221.921 & -0.4574 & 0.65952 \\
\hline ReputObj & -80.5323 & 103.154 & -0.7807 & 0.45745 \\
\hline ProfObj & 22.8786 & 23.7286 & 0.9642 & 0.36319 \\
\hline CustPress & 75.4987 & 58.1598 & 1.2981 & 0.23042 \\
\hline
\end{tabular}

\begin{tabular}{|l|c|l|l|c|}
\hline Mean dependent var & 2492.833 & & S.D. dependent var & 2665.296 \\
\hline Sum squared resid & 63302170 & & S.E. of regression & 2812.965 \\
\hline R-squared & 0.475822 & & Adjusted R-squared & -0.113878 \\
\hline F 9,8$)$ & 0.806888 & & P-value $(\mathrm{F})$ & 0.624464 \\
\hline Log-likelihood & -161.1984 & & Akaike criterion & 342.3968 \\
\hline Schwarz criterion & 351.3006 & & Hannan-Quinn & 343.6245 \\
\hline Rho & -0.421353 & & Durbin-Watson & 2.740070 \\
\hline
\end{tabular}

Table 2. Normality and heteroskedasticity result

\begin{tabular}{|c|c|}
\hline $\begin{array}{l}\text { Test for normality of residual - } \\
\text { Null hypothesis: error is normally } \\
\text { distributed. } \\
\text { Test statistic: Chi-square(2) = } \\
2.9722 \text { with p-value }=0.226253\end{array}$ & $\begin{array}{l}\text { Since the p-value of } 0.22 \text { is greater } \\
\text { than } 0.05 \text {, the null hypothesis on } \\
\text { normality test is accepted to indicate } \\
\text { that the data error is normally } \\
\text { distributed. }\end{array}$ \\
\hline $\begin{array}{l}\text { Distribution free Wald test for } \\
\text { heteroskedasticity - Null } \\
\text { hypothesis: the units have a } \\
\text { common error variance. } \\
\text { Asymptotic test statistic: Chi- } \\
\text { square }(3)=0.58173 \text { with p-value = } \\
0.900602\end{array}$ & $\begin{array}{l}\text { Since the } p \text {-value of } 0.90 \text { is greater } \\
\text { than } 0.05 \text {, the null hypothesis on } \\
\text { heteroskedasticity test is accepted to } \\
\text { indicate that the units have a } \\
\text { common error variance }\end{array}$ \\
\hline
\end{tabular}

3.2. Interpretation of result. From Tables 1 and 2, the regression result tested the relationship between external environmental pressure and environmental disclosure. Out of the seven independent variables, it is striking to note that none of the independent variables had a significant $p$-value as shown below. Therefore, the null hypothesis is rejected to indicate that within the sample and period of this study, no significant relationship exists between environmental pressure variables and environmental disclosure in the sample of banks.

Government pressure showed a $\mathrm{p}=0.23$ which is greater than the 0.05 alpha level for this research; regulatory pressure had a value of $\mathrm{p}=0.28$ which is higher than 0.05 ; social pressure had a p-value of 0.28 , which is higher than 0.05 , political pressure had a value of $p=0.65$, which is higher than 0.05 ; customer pressure had a value of $p=0.23$, which is higher than 0.05 , reputation objective had a value of $\mathrm{p}=0.45$, which is higher than 0.05 and profit objective had a value of $p=0.36$, which is higher than 0.05 . These findings are discussed under the (discussion of findings) section that follows.

\begin{tabular}{|l|l|}
\hline \multicolumn{1}{|c|}{ Test 2 significance levels } & p-value \\
\hline Independent variables & 0.23073 \\
\hline RegPress & 0.28243 \\
\hline GovPress & 0.10267 \\
\hline SocPress & 0.85525 \\
\hline PolitPress & 0.65952 \\
\hline ReputObj & 0.45745 \\
\hline ProfObj & 0.36319 \\
\hline CustPress & 0.23042 \\
\hline
\end{tabular}

\section{Discussion of findings}

This research was aimed at providing answers to the main research question, namely, what relationship exists between external environmental pressure and environmental disclosure in South African banks? Research data on the dependent variables (environmental disclosure), as well as the data on seven independent variables (government pressure, social pressure, customer pressure, regulatory pressure, political pressure), and two control variables (profit objective and reputational objective) were collected from secondary sources, which is from the annual sustainability reports of sample banks. The data were collected through content counting of the number of words appearing in the relevant environmental disclosure of each bank's integrated reports.

The number of the sample of banks used for this analysis was finally reduced to three banks, because these three banks reported all the variables consistently over the six years of data gathering period. This lack of data on all the purposed banks for this study is a first sign that disclosure of environmental issues in the integrated reports of most banks is still a little weak, which therefore requires improved external pressure to ignite the banks' environmental commitments. 
Research data gathering was for the years between 2010 and 2015, the justification as stated in section 2 of this research is that the King III Code of Corporate Governance, which requires the preparation of integrated reports (containing environmental disclosure), was released in 2009 , but became effective in 2010 .

Therefore, data were arranged and a panel data analysis was applied, which thus gave 18 observations, and these were analyzed using the multiple regression statistics run on the Statistical Package of Social Sciences (SPSS). The significance or alpha level for this analysis was set at an alpha $(\alpha)$ of $0.05(5 \%)$, which thus means that each of the independent variables was assumed to have a significant relationship with environmental disclosure only if the resulting $p$-value from the regression statistics was less than or equal to 0.05 $(\mathrm{P} \leq 0.05)$.

The analysis and findings on the research question which examined the relationship between external pressure and bank environmental disclosure showed a lack of significance between external pressure and environmental disclosure in the sample banks.

The negative findings from the analysis of data on the research question show an unusual result wherein none of the external pressure variables showed a significant relationship with environmental disclosure, as all the independent variables had a p-value greater than the alpha level of 0.05 . This non-significant relationship with environmental disclosure might coincide with perception in the literature that banks' operations attract little external pressure about their impact on the environment (Orsato, De Campos, Barakat, Nicolletti, \& Monzoni, 2015). However, the non-significant relationship between external pressure and environmental disclosure in this research is contrary to previous research findings, which highlight that external pressure does affect environmental performance and disclosure of such performance (Boiral \& HerasSaizarbitoria, 2015; Nobanee \& Ellili, 2016; Weber, 2016). This finding about the non-significant relationship between external pressure and banks' environmental disclosure should motivate future researchers to further research toward finding other factors (apart from external pressure) that spur South African banks' environmental disclosure. From the practical perspective, institutional investors' voices might improve banks' response to external pressure about environmental disclosure; therefore, there is a need for improved institutional pressure on banks' sustainability disclosure.

\section{Recommendations}

Based on the foregoing discussions, the paper makes the following recommendations for research and practice.
- Future research should expand the number of banks by including other financial institutions. By then, it is hoped that more banks would have included their external pressure variables in the sustainability reports. Studying more banks would allow for a wider generalization of research findings to improve on these present research findings.

- It is also suggested that more research should be conducted to ascertain why external pressure is not very effective in motivating banks' environmental disclosure as found in this study. Such a study might use a different method such as questionnaires to ask bank sustainability officers what their feelings are about stakeholders' environmental pressure on banks. This is important as none of the external pressure variables showed a significant relationship with the banks' environmental disclosure within the sample of banks where secondary data were collected.

This research has made a modest contribution to research on corporate environmental disclosure uniquely within the banking sector. To the best of researchers' knowledge, no research in corporate environmental disclosure in South Africa has concentrated on external environmental pressure variables using seven independent variables (regulatory pressure, government pressure, social pressure, political pressure, reputation objective, profit objective and customer pressure).

\section{Conclusion}

The objective of this study was to find whether a relationship exists between external pressure and environmental disclosure. However, all the independent variables showed a non-significant relationship with environmental disclosure.

The non-significant findings from the analysis of data highlights a striking result; this shows that the banks whose data were used are more affected by internal pressure toward social disclosure than external pressure affects them toward environmental disclosure. Therefore, although the two disclosures constitute sustainability disclosure, but to enable a clearer view of companies' influential factors to disclose, it is important to examine social disclosure separately from environmental disclosure in order to visualize which disclosure is responsive to external pressure. This research assumes that the non-significant relationship of external pressure with environmental disclosure might coincide with some perception in the literature that banks' operations attract little external pressure about their impact on the environment (Orsato, De Campos, Barakat, Nicolletti, \& Monzoni, 2015). 
Based on the findings and discussions in the previous sections, this research therefore made some recommendations for research and practice which includes that future researchers should expand the number of banks by including other financial institutions, the comparison of sustainability disclosure in banks before and after the King III report, more improved teaching and research on banking sector sustainability disclosure in higher institutions, communication of research results such as on the banking industry's sustainability to practitioners and to government agencies. Other recommendations include the need to conduct a regional study to include other African countries on banking sector sustainability and to conduct a survey study on external pressure on the banking sector's environmental activity and disclosure. This is important because currently South African banks engage in environmental disclosure, but further research should check if other factors apart from external environmental pressure make the banks to engage in environmental disclosure, for example, Weber's (2016) research indicated that banks might be motivated purely by strategic reasons rather than pressure. While previous research has combined environmental disclosure into one word 'sustainability', this research adds something new in the examination of sustainability disclosure by separating the sustainability contents through a careful isolation of environmental disclosure as a standalone sustainability disclosure.

\section{References}

1. Adams, C. A. (2004). The ethical, environmental reporting-performance portrayal gap. Accounting, Auditing \& Accountability Journal, 17(5), 731-757.

2. Amran, A., \& Haniffa, R. (2011). Evidence in development of sustainability reporting: acase of a developing country. Business Strategy and the Environment, 20(3), 141-156.

3. Arnold, M. C., Bassen, A., \& Frank, R. (2013). Integrating sustainability reports into financial statements: an experimental study. Retrieved from http://www.dvfa.de/fileadmin/downloads/Publikationen/Artikel/ (accessed on October 1, 2016).

4. Boiral, O., \& Heras-Saizarbitoria, I. (2015). Managing Biodiversity Through Stakeholder Involvement: Why, Who, and for What Initiatives? Journal of Business Ethics, 1-19.

5. Barbu, E. M., Dumontier, P., Feleagă, N., \& Feleagă, L. (2014). Mandatory Environmental Disclosures by Companies Complying with IASs/IFRSs: The Cases of France, Germany, and the UK. The International Journal of Accounting, 49(2), 231-247.

6. Brennan, N. M., \& Merkl-Davies, D. M. (2014). Rhetoric and argument in environmental reporting: The Dirty Laundry case. Accounting, Auditing \& Accountability Journal, 27(4), 1-11.

7. Canham, C. D. W., Cole, J., \& Lauenroth, W. K. (Eds.). (2003). Models in ecosystem science. Princeton: Princeton University Press.

8. Cho, C. H., \& Patten, D. M. (2013). Green accounting: reflections from a CSR and environmental disclosure perspective. Critical Perspectives on Accounting, 24(6), 443-447.

9. Creswell, J. W. (2014). A concise introduction to mixed methods research. SAGE Publications: London.

10. De Villiers, C., Rinaldi, L., \& Unerman, J. (2014). Integrated Reporting: Insights, gaps and an agenda for future research. Accounting, Auditing \& Accountability Journal, 27(7), 1042-1067.

11. Dingwerth, K., \& Eichinger, M. (2014). Tamed Transparency and the Global Reporting Initiative: The Role of Information Infrastructures. Transparency in Global Environmental Governance: Critical Perspectives, 225. MIT Press: Massachusetts.

12. Epstein, M. J., \& Buhovac, A. R. (2014). Making sustainability work: Best practices in managing and measuring corporate social, environmental, and economic impacts. San Francisco: Berrett-Koehler Publishers.

13. Font, X., Guix, M., \& Bonilla-Priego, M. J. (2016). Corporate social responsibility in cruising: Using materiality analysis to create shared value. Tourism Management, 53, 175-186.

14. Glozer, S., Caruana, R., \& Hibbert, S. A. (2014). Constructing Legitimacy in Online Corporate Social Responsibility Communication. Academy of Management Proceedings, 1, 15051.

15. Hogarth, K., Hutchinson, M., \& Scaife, W. (2016). Corporate Philanthropy, Reputation Risk Management and Shareholder Value: A Study of Australian Corporate giving. Journal of Business Ethics. http://dx.doi.org/10.1007/s10551-016-3205-8

16. Hahn, R., \& Kühnen, M. (2013). Determinants of sustainability reporting: A review of results, trends, theory, and opportunities in an expanding field of research. Journal of cleaner production, 59, 5-21.

17. Hahn, R., \& Lülfs, R. (2014). Legitimizing negative aspects in GRI-oriented sustainability reporting: A qualitative analysis of corporate disclosure strategies. Journal of business ethics, 123(3), 401-420.

18. Hassan, A., \& Ibrahim, E. (2012). Corporate environmental information disclosure: factors influencing companies' success in attaining environmental awards. Corporate Social Responsibility and Environmental Management, $19(1), 32-46$.

19. Ihlen, Ø., \& Roper, J. (2014). Corporate reports on sustainability and sustainable development:'We Have Arrived'. Sustainable development, 22(1), 42-51. 
20. James, M. L. (2015). Advantages and Disadvantages Of Sustainablity Reporting: A Study Exploring Accounting Majors' perceptions. Proceedings of Allied Academies International Conference. Academy of Legal, Ethical and Regulatory Issues, 19(1), 8. Jordan Whitney Enterprises, Inc.

21. JSE (2014). JSE investor briefing. Retrieved from https://www.jse.co.za/content/JSEPresentationItems/2014-ESGInvestor-Briefing.pdf (accessed on October 1, 2016).

22. Kolk, A., \& Levy, D. (2001). Winds of Change: Corporate Strategy, Climate change and Oil Multinationals. European Management Journal, 19(5), 501-509.

23. Kolk, A., \& Perego, P. (2010). Determinants of the adoption of sustainability assurance statements: An international investigation. Business Strategy and the Environment, 19(3), 182-198.

24. Ledoux, M. J., Cormier, D., \& Houle, S. (2014). Customer Value Disclosure and Analyst Forecasts: The Influence of Environmental Dynamism. Management Decision, 52(3), 3-13.

25. Legendre, S., \& Coderre, F. (2013). Determinants of GRI G3 application levels: the case of the fortune global 500. Corporate Social Responsibility and Environmental Management, 20(3), 182-192.

26. Llena, F., Monveva, J. M., \& Hernandez, B. (2007). Environmental disclosures and compulsory accounting standards: the case of Spanish annual reports. Business Strategy and the Environment, 16(1), 50-63

27. Mallin, C., Michelon, G., \& Raggi, D. (2013). Monitoring Intensity and Stakeholders' Orientation: How Does Governance Affect Environmental Disclosure? Journal of business ethics, 114(1), 29-43.

28. Manetti, G., \& Toccafondi, S. (2014). Defining the Content of Sustainability Reports in Nonprofit Organisations: Do Stakeholders Really Matter? Journal of Nonprofit \& Public Sector Marketing, 26(1), 35-61.

29. Meng, X. H., Zeng, S. X., \& Tam, C. M. (2013). From voluntarism to regulation: A study on ownership, economic performance and corporate environmental information disclosure in China. Journal of business ethics, 116(1), $217-232$.

30. Meng, X. H., Zeng, S. X., Shi, J. J., Qi, G. Y., \& Zhang, Z. B. (2014). The relationship between corporate environmental performance and environmental disclosure: An empirical study in China. Journal of environmental management, 145, 357-367.

31. Nobanee, H., \& Ellili, N. (2016). Corporate sustainability disclosure in annual reports: Evidence from UAE banks: Islamic versus conventional. Renewable and Sustainable Energy Reviews, 55, 1336-1341.

32. Naimi, A. (2011). Sustainability Issues in the Petroleum Refining Industry: A Case Study of Shell. Otago Management Graduate Review, 9, 93-113.

33. Orsato, R. J., De Campos, J. G. F., Barakat, S. R., Nicolletti, M., \& Monzoni, M. (2015). Why join a carbon club? A study of the banks participating in the Brazilian "Business for Climate Platform". Journal of Cleaner Production, 96, 387-396.

34. Peters, G. F., \& Romi, A. M. (2013). Does the voluntary adoption of corporate governance mechanisms improve environmental risk disclosures? Evidence from greenhouse gas emission accounting. Journal of Business Ethics, 1-30.

35. Sen, A. (2013). The ends and means of sustainability. Journal of Human Development and Capabilities, 14(1), 6-20.

36. Soltani, B., \& Maupetit, C. (2014). Importance of core values of ethics, integrity and accountability in the European corporate governance codes. Journal of Management \& Governance, 1-26.

37. Stubbs, W., \& Higgins, C. (2014). Integrated Reporting and internal mechanisms of change. Accounting, Auditing \& Accountability Journal, 27(7), 1068-1089.

38. Stubbs, W., Higgins, C., \& Milne, M. (2013). Why do companies not produce sustainability reports? Business Strategy and the Environment, 22(7), 456-470.

39. Talbot, D., \& Boiral, O. (2014). Strategies for climate change and impression management: A case study among Canada's large industrial emitters. Journal of Business Ethics, 1-18.

40. Tilt, C. A. (2001). Influences on corporate social disclosure: a look at lobby groups ten years on. Commerce Research Papers, No.04-1 - Flinders University. Retrieved from http://www.flinders.edu.au/sabs/businessfiles/research/papers/2004/04-1.pdf (accessed on January 8, 2015).

41. Tilt, D. D, \& Xydias-Lobo, M. (2016). Sustainability reporting by publicly listed companies in Sri Lanka. Journal of Cleaner Production, 129, 169-182.

42. Weber, O. (2016). The Sustainability Performance of Chinese Banks: Institutional Impact. Retrieved from https://papers.ssrn.com/sol3/papers.cfm?abstract_id=2752439 (accessed on August 3, 2016).

43. Weaver, G. R., Trevino, L. K., \& Cochran, P. L. (1999). Corporate ethics programs as control systems: Influences of executive commitment and environmental factors. Academy of Management Journal, 42(1), 41-57.

44. Wolf, J. (2014). The relationship between sustainable supply chain management, stakeholder pressure and corporate sustainability performance. Journal of business ethics, 119(3), 317-328.

45. World Commission on Environment and Development (WCED) (1987). Our common future (The Brundtland Report). Oxford University Press, Oxford.

46. Yilmaz, I. (2016). Social Performance vs. Financial Performance: CSR disclosures as an indicator of Social Performance. International Journal of Finance \& Banking Studies, 2(2), 53-65. 